Canadian Journal of Bioethics

ItCB

Revue canadienne de bioéthique

\title{
Review of: Zlotnik Shaul, R. (ed.) (2014) Paediatric Patient and Family-Centred Care: Ethical and Legal Issues
}

\section{Marla Sharp}

Volume 1, Number 2, 2018

URI: https://id.erudit.org/iderudit/1058283ar

DOI: https://doi.org/10.7202/1058283ar

See table of contents

Publisher(s)

Programmes de bioéthique, École de santé publique de l'Université de Montréal

ISSN

2561-4665 (digital)

Explore this journal

Cite this review

Sharp, M. (2018). Review of [Review of: Zlotnik Shaul, R. (ed.) (2014) Paediatric Patient and Family-Centred Care: Ethical and Legal Issues]. Canadian Journal of Bioethics / Revue canadienne de bioéthique, 1(2), 77-77.

https://doi.org/10.7202/1058283ar 


\section{Review of: Zlotnik Shaul, R. (ed.) (2014) Paediatric Patient and Family-Centred Care: Ethical and Legal Issues}

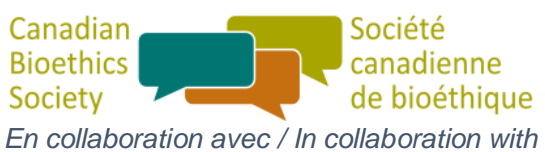

Marla Sharp ${ }^{1}$

Mots clés

pédiatrie, patient, centré sur la famille, soins, éthique, droit

Keywords
paediatric, patient, family-centred, care, ethics, law

Paediatric Patient and Family-Centred Care: Ethical and Legal Issues [1] introduces readers to a collaborative approach to patient care that is quickly gaining acceptance and support across various levels of the healthcare spectrum - one in which members of the patient's family are also recognized as care recipients, and thus care is planned around the entire family unit. This type of care requires healthcare teams to respect and respond to the specific needs, values, and desires of the patient and family and to ensure that these principles and factors have a functional role in all clinical decisions.

The text provides readers with a wide range of relevant and engaging works, written by knowledgeable Canadian experts from various fields, including bioethics, law, medicine, health policy, nursing, philosophy, and social work, among others. Sections and chapters are intuitively organized in such a way that facilitates a cohesive understanding, despite a relative lack of definitional unity across fields of practice compared to more traditional care models. This work provides an inclusive and enthusiastic approach to this topic, and its approach differs from that of other published works in the area of paediatric patient and family-centred care models insofar as it features significant discussion of both ethical and legal deliberations rather than one or the other. Furthermore, the authors' frequent use of case studies makes for informed understanding of the contemporary, real-world benefits and challenges that arise when implementing variations of this type of care model.

Some of the most notable advantages of Patient and Family-Centred Care (P\&FCC) approaches include greater patient and family satisfaction, better overall health outcomes, fewer lawsuits, and reductions in rehospitalizations and referrals to specialists [2]. However, there remain some substantial issues, some of the most problematic pertaining to resource allocation [2], physician concerns about losing their role as primary healthcare providers and the practicality of involving family members in care planning [3], and difficulties determining who makes up the family unit [4]. The articles within this text come together to provide a strong explanation and analysis of P\&FCC in paediatric care settings; one that would be particularly useful for organizations or institutions (and for the professionals that work within them) that are interested in learning more about this care model when considering whether or not to implement it into their current care practices, or conversely, for those that may have already begun to implement these types of 'synergistic' [3] approaches to care and are seeking insight for optimization purposes.

\section{Conflit d'intérêts}

Aucun déclaré
Conflicts of Interest

None to declare

Édition/Editors: Christy Simpson \& Patrick Gogognon

Affiliations

${ }^{1}$ New York University, New York, USA

Correspondance / Correspondence: Marla Sharp, sharpmarlac@gmail.com

Reçu/Received: 9 Oct 2018

Publié/Published: 25 Oct 2018 (CBS/SCB: Jul 2017)

Les éditeurs suivront les recommandations et les procédures décrites The editors follow the recommendations and procedures outlined in dans le Code of Conduct and Best Practice Guidelines for Journal the COPE Code of Conduct and Best Practice Guidelines for Journal Editors de COPE. Plus précisément, ils travaillent pour s'assurer des Editors. Specifically, the editors will work to ensure the highest ethical plus hautes normes éthiques de la publication, y compris standards of publication, including: the identification and management l'identification et la gestion des conflits d'intérêts (pour les éditeurs et of conflicts of interest (for editors and for authors), the fair evaluation pour les auteurs), la juste évaluation des manuscrits et la publication of manuscripts, and the publication of manuscripts that meet the de manuscrits qui répondent aux normes d'excellence de la revue. journal's standards of excellence.

\section{References}

1. Zlotnik Shaul R. (ed.). Paediatric Patient and Family-Centred Care: Ethical and Legal Issues. New York: Springer, 2014.

2. Gibson J. Resource allocation in paediatric patient and family-centred care, in R Zlotnik Shaul (ed.), Paediatric Patient and Family-Centred Care: Ethical and Legal Issues. New York: Springer, 2014; p. 35-54.

3. Sheahan L, Da Silva M, Czoli C, Zlotnik Shaul R. A Canadian perspective on a child's consent to research within a context of family-centred care: from incompatibility to synergy, in R Zlotnik Shaul (ed.), Paediatric Patient and Family-Centred Care: Ethical and Legal Issues. New York: Springer, 2014; p. 19-34.

4. Chapman L. Accounting for the family in law: an impartial but not impersonal point of view, in R Zlotnik Shaul (ed.), Paediatric Patient and Family-Centred Care: Ethical and Legal Issues. New York: Springer, 2014; p. 97-114. 